\title{
Pathological Changes of Mycobacterium Tuberculosis and Treatments with Alcoholic Extract of Arachis hypogaea and Ethambutol in Mice
}

\author{
Ban Sahib Al-Nasiry ${ }^{1 *}$, Maysoon Sabah Abbas ${ }^{1}$, Suhair Hussan Al-Qutbi ${ }^{2}$
}

${ }^{1}$ Zoonotic diseases unit, College of Veterinary Medicine; ${ }^{2}$ College of Pharmacy, Baghdad University, Baghdad, Iraq.

\begin{abstract}
The aim of this study is to demonstrate the histopathological changes of alcoholic extract of Arachis hypogaea and ethambutol in increasing the therapeutic efficacy of anti-tuberculosis in treatment of mice infected with mycobacterium tuberculosis. 30 white Swisrland mice of 6-8 weeks age, weighted 20-25gm were used they were randomly divided into 3 groups which infected with mycobacterium tuberculosis ( $\left.1 \times 10^{8} \mathrm{cfu}\right)$, after one month of infection we treated (2) groups: one of them treated with ethambutol \& the other treated with ethambutol + alcoholic extract and third group was contral positive. At 60 day post infection all animals were scarified and samples from different organs (liver, lungs, kidneys, spleen, and intestine) were fixed in $10 \%$ neutral buffered formalin for histopathological examination. The result of present study revealed no lesion or mild of internal organs of animal that treated with extract + ethambutol comparing with animal group treated with ethambutol only that showed moderate lesion while infected animal group showed sever pathological lesion characterized by granulomatous lesion in liver and lung also congestion with degenerative changes seen in kidney.
\end{abstract}

Keywords | Mycobacterium Tuberculosis, Alcoholic extract, Arachis hypogaea

Editor | Kuldeep Dhama, Indian Veterinary Research Institute, Uttar Pradesh, India.

Received | August 10, 2016; Accepted | August 22, 2016; Published | September 28, 2016

*Correspondence | Ban S Al-Nasiry, Zoonotic diseases unit, College of Veterinary Medicine, Baghdad University, Baghdad, Iraq; Email: ban.Sahib@yahoo.com

Citation | Al-Nasiry BS, Abbas MS, Al-Qutbi SH (2016). Pathological changes of Mycobacterium Tuberculosis and treatments with alcoholic extract of Arachis

hypogaea and ethambutol in mice. Adv. Anim. Vet. Sci. 4(9): 489-493.

DOI | Http://dx.doi.org/10.14737/journal.aavs/2016/4.9.489.493

ISSN (Online) | 2307-8316; ISSN (Print) | 2309-3331

Copyright (c) $2016 \mathrm{Al}$-Nasiry et al. This is an open access article distributed under the Creative Commons Attribution License, which permits unrestricted use, distribution, and reproduction in any medium, provided the original work is properly cited.

\section{INTRODUCTION}

$\mathrm{M}$ edicinal plants play an important role in the life of people they used these plants in their daily lives in meals \&traditional medicine (Aliasghar et al., 2015). Peanut belongs to the Fabaceae family within Fabaceae Faboideae and its fruit is very distinctive grow underground, they consists of chemically Palmatic acid, Oleic acid, proteins and vitamins $B_{1}, B_{2}, B_{6}$ and Lecithin as well as phenolic compounds is a strong antioxidant, that prevent the oxidation of lipids or other molecules and inhibition of oxidative chain reaction. The peanuts also contain sugars, dietary fiber, saturated and unsaturated fats and metals (Lee et al., 2007). Tuberculosis is a common and often deadly infectious chronic disease caused by mycobacterium. A third of world's population are thought to be infected with M. tuberculosis (Kumer et al., 2007; Jasmer et al., 2002). The infection begins when the mycobacte- rium reach the pulmonary alveoli where they invade and replicate within the endosomes of alveolar macrophages (Schon and Stendahi, 2013; Houben et al. 2006). The infectious dose of tuberculosis is very low and inhaling less than 3 bacteria may cause an infection (Nicas et al., 2005). Effective tuberculosis treatment is difficults due to unusual stracture and chemical composition of mycobacterial cell wall which makes many antibiotics ineffective and hinders the entry of drugs (Brennan and Nikaido, 1995; Acharya and Goldman, 1970).

This microorganism have multidrug resistant (Newton et al., 2009). So there was a trend towards medicinal plants to see active materials and there role in the inhibition of mycobacterium tuberculosis (Lee et al., 2007). One of these plants is peanut (Arachia bypogaea) which is abundance in many countries especially the warm one used as food as well as the effectiveness as antioxidant (Gupta et al., 2009). 
OPEN OACCESS

Peanuts are known to be rich in L-arginine and supplementation of nutrition rich in arginin may shorten duration of treatment as well as increase recovery in tuberculosis patients (Schon et al., 2003), Arginine increase nitrogen dioxide level which has a role in stimulating the body defences, patient show shorter duration of cough, increased weight gain and higher seputum conversion rate, all tuberculosis patients had lower levels of plasma L-arginine than healthy one (Wood et al., 2010). Therefor, the aim of this study is to demonstrate the effect of Arachis hypogaea and ethambutol on mice infected with mycobecterim tuberculosis.

\section{MATERIALS AND METHODS}

\section{BACTERIAL ISOLATES}

Mycobacterium Tuberculosis Isolates were obtained from tuberculosis institute in Baghdad, the biochemical test were done to these Isolates to confirm their diagnosis and identification (Quinn et al., 2004).

\section{Culture Media}

Lowenstein media which is a special media for mycobacterium tuberculosis is prepared according to the production manuals (Quinn et al., 2004).

\section{Determination of Peanuts Extract}

The plants were first dried and ground to powder, then 100 $\mathrm{g}$ of plant soaked in $500 \mathrm{ml}$ of $70 \%$ ethanol for $24 \mathrm{hr}$, then separated using separator funnel, subsequently filtered through Whattman filter paper No. 1 and filtrate dried.The dried extracted was weighted for prepare the stock solution by dissolved $1 \mathrm{~g}$ of extract in $5 \mathrm{ml}$ of distal water to prepare concentration $200 \mathrm{mg} / \mathrm{ml}$. Then the $\mathrm{PH}$ was measured \& nominate solution using whatman paper $4.5 \mathrm{~m}$ and saved in the refrigerator until use (Anessing and Perez, 1993).

\section{Determination of Challenge Dose}

The preparation of bacterial suspension of the counting was made by using McFarland tubes according to Balasubramanian et al. (1992).

\section{DRUG USED FOR TREATMENT}

Treatment commenced 4 weeks after infection period which corresponds to the peak in primary lesion, using ethambutol which prepared in 50\% sucrose and estimated according to Smith et al. (1991).

\section{ExPERIMENTAL Design}

Thirty white swisrland mice, 6-8 weeks age were randomly divided equally into 3 groups and treated as following:

1. The $1^{\text {st }}$ group (group of infection) were inoculated intra peritonealy with $0.1 \mathrm{ml}$ of bacterial suspension contain $1 \times 10^{8} \mathrm{CFU}$ of mycoloacterium tuberculosis.

2. The $2^{\text {nd }}$ group (group of treatment with ethambutol) was treated as the $1^{\text {st }}$ group but were given $0.1 \mathrm{ml} \mathrm{eth}$ ambutol orally daily after 30 day post infection.

3 . The $3^{\text {rd }}$ group was infected and treated with 0.1 ethambutol and $0.1 \mathrm{ml}$ of alcoholic extract of Arachis bypogaea. All animals of all groups were scarified after 60 days post infection.

Post mortem examination done to all groups and recording to cross lesion and pieces $(1 \times 1 \times 1 \mathrm{~cm})$ from internal organs (liver, lungs, kidneys, spleen, intestine) were fixed in $10 \%$ normal buffered formaline for $72 \mathrm{hrs}$. Then used the routen procedure for histopathogical section preparation according to Luna (1968).

\section{RESULTS}

\section{Pathological Changes}

Congestion of most examined organs was the main gross lesion in both infected and treated groups with multiple focal granulomatous lesion in liver and lungs of infected non treated group.

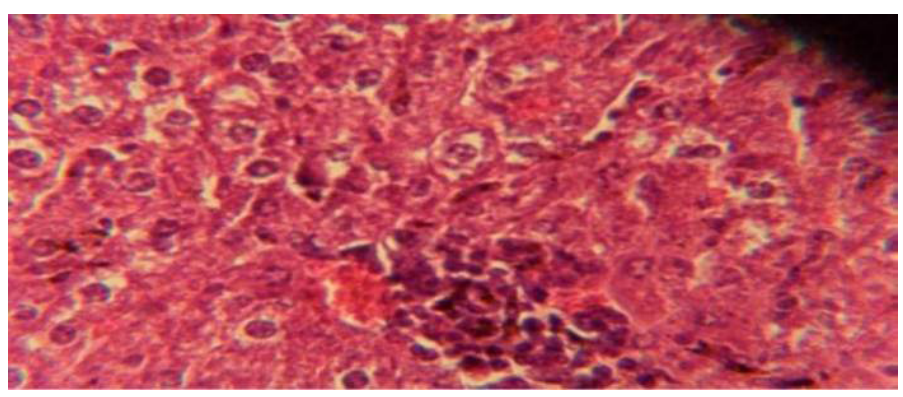

Figure 1: Histological section in liver of infected group showing multiple focal granulamatous lesion in liver parenchyma especially around central vein consist of aggregation of mononuclear cells

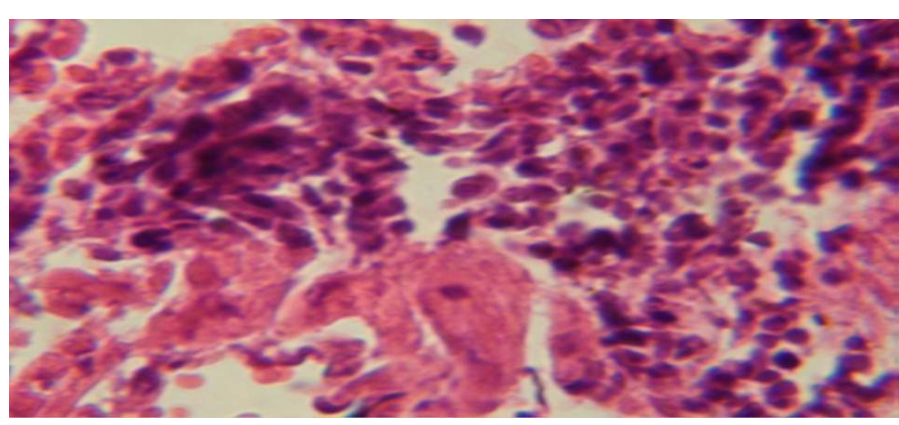

Figure 2: Histological section in lung of infected group showing large granulomatous lesion consist of aggregation of macrophages in lung parenchyma

\section{Histopathological Examination}

Thelivershows multiplefocal granulamatouslesion in parenchyma especially around central vein consist of aggregation of mononuclear cells, with vascular degeneration of hepatocytes (Figure 1) in other animal, the liver shows congestion of central vein with mononuclear cell in their lumen (Figure 2); while, there were aggregation of mononuclaur cell in liver parenchyma and proliferation of kupffer cell (Figure 3). 


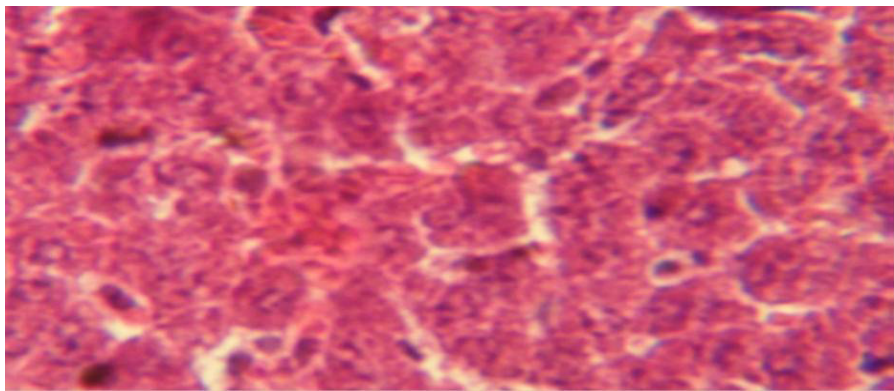

Figure 3: Histological section in liver of treatment group with ethambutol + extract showing aggregation of mononuclaur cell in liver parenchyma and proliferation of kupffer cell

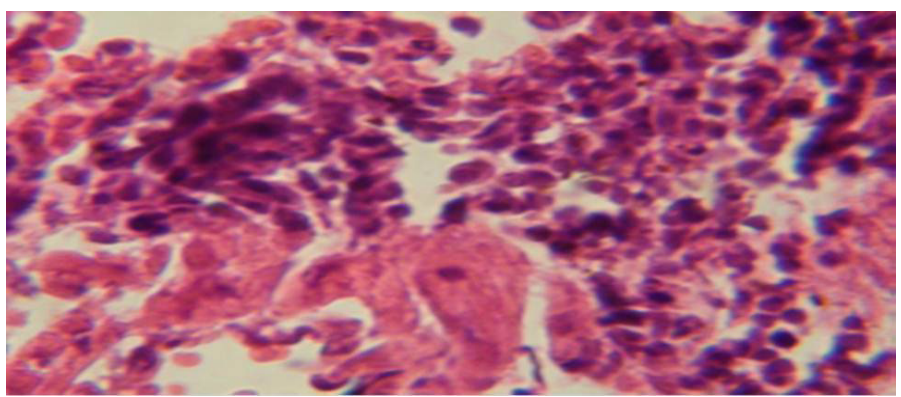

Figure 4: Histological section in lung of infected group showing large granulamatous lesion consist of aggregation of macrophages in lung parenchyma

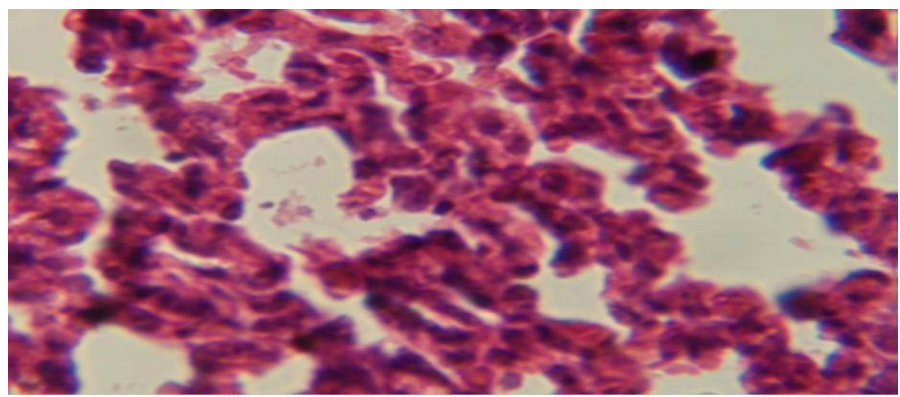

Figure 5: Histological section of lung of treatment group with ethambutol revealed congestion of blood vessel with few inflammatory cell in their lumen

The lung revealed large granulamatous lesion consist of aggregation of macrophages in lung parenchyma (Figure 4), in other animal, there were congestion of blood vessel with few inflamtory cell in their lumen (Figure 5), while Figure 6 shows aggregation of mononuclear cell in the interalveolar septa.

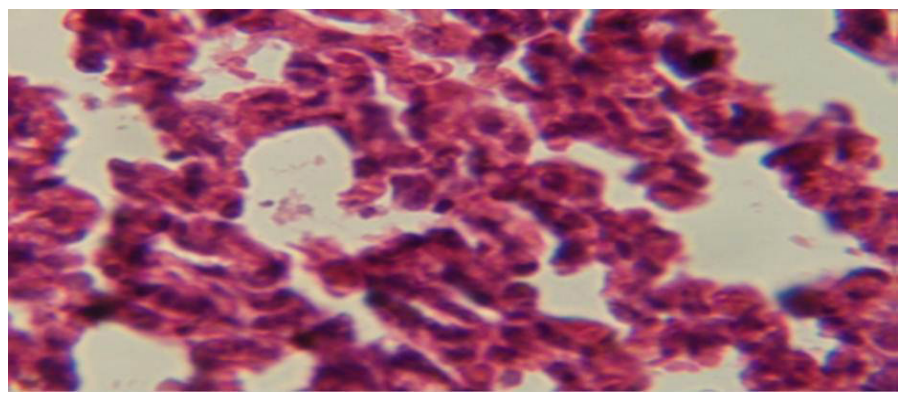

Figure 6: Histological section of lung of treatment group with ethambutol + extract showing aggregation of mononuclear cell in the interalveolar septa

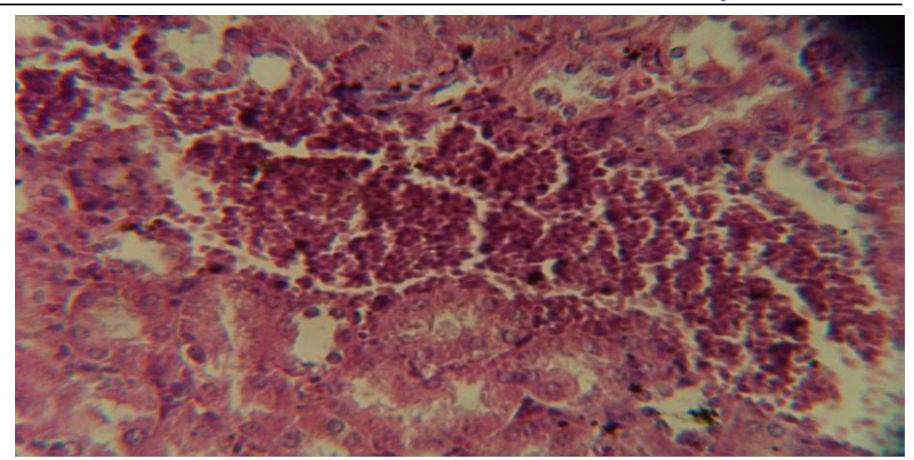

Figure 7: Histological section in kidney of infected group showing congestion of blood vessel with infiltration of inflammatory cell in their lumen

The kidney revealed congestion of blood vessel with infiltration of inflammatory cell in their lumen (Figure 7), in other animal, there were cellular degeneration of epithelial cell lining renal tubule and neutrophil infiltration in the interstitial tissue (Figure 8), while Figure 9 shows cellular degeneration of epithelial cell lining renal tubule.

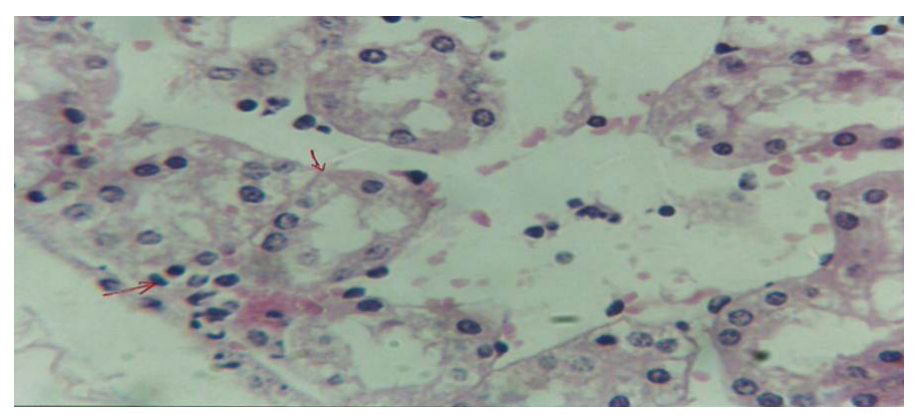

Figure 8: Histological section of kidney of treatment group with ethambutol revealed cellular degeneration of epithelial cell lining renal tubule and neutrophil infiltration in the interstitial tissue

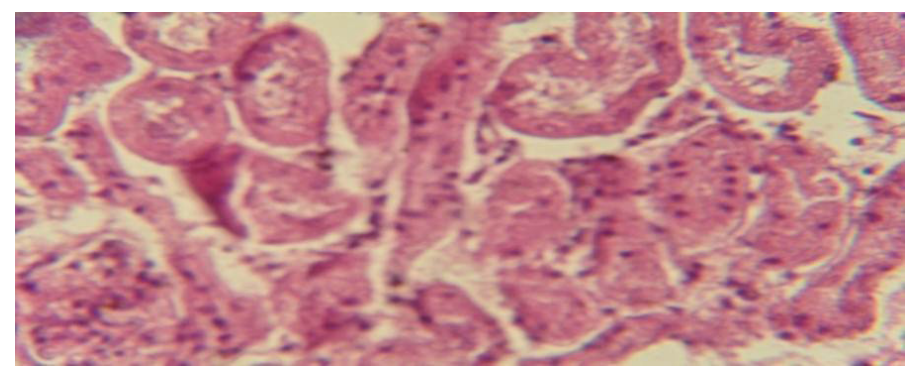

Figure 9: Histological section of kidney of treatment group with ethambutol + extract revealed cellular degeneration of epithelial cell lining renal tubule

\section{DISCUSSION}

This study showed the efficiency of alcoholic extract of Arachis hypogaea in treatment of tuberculosis which show no or very less lesion in third group (animals treated with extract + ethambutol) comparing with other groups (Newton et al., 2009) this is usually occur due to high argenine content in extract (Gupta et al., 2009; Abbas, 2011).

Arachis hypogaea enhanced cellular and humoral immune 
response, also apontent immunostimulator and it is impact may be attributed with flavonoid, proteins and minerals that present in the extract (Nagendra et al., 2015).

Argenine also may play a role in elaborate high percentage of nitrous oxide which consider as effective supporting factor to the activated macrophage (Schon et al., 2003; Wood et al., 2010). The present study shown that intra peritoneal infection does result in chronic TB infection in mice organs similar to that observed during low dose aerosol infection mentioned by (Cardona et al., 1999).

The mycobacterion tuberculosis spread through the blood stream to other tissues and organs and so all parts of body can be affected by the disease (Agarwal et al., 2005) and this agree with our result, that the M.O reach to different organs (lungs, liver, kidneys, intestine and spleen).

The study revealed that the main histopathological lesion in the examined lungs and livers of inflected animals were granuloma and these observations agreed with (Cardona et al., 2000). The absence of necrosis and langhans type cells makes the tuberculosis granulomas of mice histologically different from those arising in guinea pigs, rabbits and humans, this result supported the investigation that mentioned by (Lefford, 1984). These differential features have been related to the stronger immunological response elicited in mice, which consequently tend to sustain lesser degrees of systemic dissemination of mycobacterial infection than guinea pigs or rabbits (Orme, 1996; Converse, 1996).

Result of present study refers to the effect of arginine in elaborate high percentage of nitrous oxide which support to activated macrophage against mycobaceria. This results agree with Aliasghar et al. (2015), who found that arginine is useful as an adjunctive therapy in patient with active tuberculosis that increased production of nitric oxide and improved the response to treatment.

Virulence is the measure of pathogenicity of microorgansim as determined by it, ability to invade host tissue and produce disease, and after thirty days of infection bacilli had disseminated resulting in microscopically visible lesions in liver, spleen, lungs, these result supported by the observation of Gopinath et al. (2009).

Tuberculosis is classified as one of the granulomatous inflammatory conditions, macrophage, $\mathrm{T}$ cell, $\mathrm{B}$ cell and fibroblasts are among the cells that aggregate to form granuloma with lymphocytes surrounding the inflected macrophages. $T$ lymphocyte secrete cytokines such as interferon gamma which activate macrophages to destroy bacteria (Kaufman, 2002).

The treatment with ethambutol resulted in significant re- duction in pathological lesion in different organs and our result is agreed with Dickinson and Mitchison (1976) who use aguinea pig as amodel of infection.

Ethambutol inhibits arabinosyl transferase-an enzyme that is important for the synthesis of the mycobacterial arabinogalactan cell wall (Richard and Mary, 2006).

\section{ACKNOWLEDGMENTS}

Many thanks to Zoonotic Diseases Research Unit of the Faculty of Veterinary Medicine/University of Baghdad, for their help.

\section{CONFLICT OF INTEREST}

There is no conflict for this research.

\section{AUTHORS' CONTRIBUTION}

Ban AL- Nasiry \& Maysson Abbas: collection of human tuberculosis bactrerium and preperation of ethambuttol and Alcoholic extract Peanuts, in addition to the lab work. Suhair Al-Qutbi: reading the histopathological changes.

\section{REFERENCES}

-Abbas MS (2011). The effect of some plants extract on growth of mycobacterium tuberculosis in comparsion with ethambutol. Iraq J. Vet. Med. 35(1): 129-134.

-Acharya PV, Goldman DS (1970). Chemical composition of the cell wall of the H37Ra strain of mycobacterium tuberculosis. J. Bacteriol. 102(3): 733-739.

- Agarwal R, Malhotra P, Awasthi A, Kakkar N, Gupta, D (2005). Tuberculosis ditated cardiomyopathy: An underrecognized entity? BMC Infect. Dis. 5(1): 29. http://dx.doi. org/10.1186/1471-2334-5-29

- Aliasghar F, Omid S, Masoomeh S, manijeh K (2015). Arginine adjunctive therapy in active tuberculosis. Tuberculosis Research and Treatment, Hindawi Publishing Corporation, Pp. 5.

-Anessing G, Perez C (1993). Screening of plants used a green line. J. Ethnopharmacol. 39: 119-128.

-Balasubramanian V, Guo-Zhi W, Wiegeshaus E, Smith D (1992). Virulence of Mycobacterium Tuberculosis for Guinea pigs: A quantitative modification of the assay developed by Mitchison. Int. J. Tuberc. Lung Dis. 73: 268-272. http:// dx.doi.org/10.1016/0962-8479(92)90131-3

-Brennan PJ, Nikaido H (1995). The envelope of mycobacteria. Annu. Rev. Biochem. 64: 29-63. http://dx.doi.org/10.1146/ annurev.bi.64.070195.000333

- Cardona PJ, Cooper A, Luguin M (1999). The intravenous model of murine tuberculosis in less pathogenic than the aerogenic model owing to a more rapid induction of systemic immunity. Scand. J. immunol. 49: 362-366. http://dx.doi. org/10.1046/j.1365-3083.1999.00522.x

- Cardona PJ, Latjos RL, Gordillo J, Ojanguren ID, Ariza A, Ausina A (2000). Evolution of granuloma in lungs of mice 
infected aeroginically with Mycoboterium tuberculosis. Scand. J. Immunol. 52: 156-163. http://dx.doi.org/10.1046/j.13653083.2000.00763.x

- Converse PJ (1996). Cavitary tuberculosis produced in rabbits by aerosolized virulent tubercle bacilli. Infect. Immune. 64 : 4776-4787.

-Dickinson JM, Mitchison DA (1976). Bactericidal activity in vitro and in guinea pig of isoniazid, rifampicin and ethambutol. Tubercle. 57: 251-258. http://dx.doi. org/10.1016/S0041-3879(76)80002-5

- Gopinath S, Smith EP, Crystal AS, Diane JO, Ian MO, Randall JB (2009). Disseminated disease severity as a measure of virulence of mycobacterium tuberculosis in guinea pig model. Tuberculosis. 8(4): 295-306.

- Gupta KB, Gupta R, Atreja A, Verma M, Vishvkarma S (2009). Tuberculosis and nutrition. Lung India. 26: 9-16. http:// dx.doi.org/10.5005/jp/books/10992_5

-Houben E, Nguyen L, Pieters J (2006). Interaction of pathogenic mycobacteria with the host immune system. Curr. Opin. Microb. 9(1): 76-85. http://dx.doi.org/10.1016/j. mib.2005.12.014

- Jasmer RM, Nahid P, Hopewell P (2002). Clinical practice, latent tuberculosis. N. Eng. J. Med. 347(23): 1860-1866. http://dx.doi.org/10.1056/NEJMcp021045

-Kaufmann S (2002). Protection against tuberculosis: Cytokines, T cells and macrophages. Rheum Dis. 61(Suppl 2): 54-58. http://dx.doi.org/10.1136/ard.61.suppl_2.ii54

- Lee JH, Baek IY, Kang NS, Ko J, Kim HS, Park KY, Ahn YS, Suh DVY, Ha TJ (2007). Identification of phenolic compounds and antioxidant: Effects From the exudates of germinating peanut (Arachis hypogaea). Food Sci. Biotechnol. 16(1): 2936.

-Lefford MJ (1984). Disease in mice and rats.In: The mycobacteria (ed. Kubica GP), A source book. Marcel Dekker Inc., New York. Pp. 947-977.

-Luna LG (1968). Manual of histology saining methods of the armed forces institute of pathology $3^{\text {rd }}$ ed. Mcgrow Hill Book Co., New York.

- Nagendra LB, Ashok P, Surana YS, Srivastava R, Madharkhandi
A, Razzak AK (2015). Immunomodulatory activity of aqueou extract of Arachis hypogaea seeds (Fabaceae) in rats. Int. J. Pharm. Sci. Rev. Res. 34(2): 130-134.

-Newton S, Laus M, Wright CW (2009). A review of antimicrobial natural products. Res. J. Phytother. 14(5): 303:322.

-Nicas M, Nazaroff WW, Hubbard A (2005). Toward understanding the risk of secondary air borne infection: emission of respirable pathogens.J.Occup.Environ.Hyg.2(3): 143-54. http://dx.doi.org/10.1080/15459620590918466

- Orme IM (1996). The immune response to tuberculosis in animal models. Tuberculosis. Little Brown and Co., Boston. Pp. 269-280. http://dx.doi.org/10.1007/978-3-642-801662_8

-Quinn PJ, Carter ME, Markey B, Carter GR (2004). Clinical veterinary microbiology. $6^{\text {th }}$ ed. Mosby Animp. Wolf, London.

-Richard DH, Mary JM (2006). Lippincott's illustrated Reviews $3^{\text {rd }}$ edition, Lippincott's Williams and Wilkins, Philadelphia. Pp. 399.

-Schon T, Elias D, Moges F, Melese E, Tessema T, Stendahl O, Britton S, Sundqvist T (2003). Arginine as an adjuvant to chemotherapy Improves clinical outcome in active tuberculosis. Eur. Respir. J. 21: 483-488. http://dx.doi.org/1 0.1183/09031936.03.00090702

-Schon T, Lerm M, Stendahi O (2013). Shortening the shortcourse therapy- insights into host immunity may contribute to new treatment strategies for tuberculosis. Assoc. Pub. J. Internal Med. 273: 368- 382. http://dx.doi.org/10.1111/ joim.12031

-Smith DW, Balasubramanian V, Wiegeshaus E (1991). A guinea pig model of experimental airborne tuberculosis for evaluation of the response to chemotherapy: the effect on bacilli in the initial phase of treatment. Tubercle. 72: 223231. http://dx.doi.org/10.1016/0041-3879(91)90013-I

-Wood R, Roberston SJ, Uys P, Hargrove J, Middelkoop K, Lawn SD, Bekker LG (2010). Tuberculosis transmission to young children in a South African Community; modeling household and community infection risks. Clin. Infect. Dis. 51: 401-408. http://dx.doi.org/10.1086/655129 